\title{
Turkish Adaptation of Change Fatigue Scale: A Study of Reliability and Validity
}

\author{
İbrahim LIMMON*
}

\begin{abstract}
This study adapts "Change Fatigue Scale" into Turkish cultural context for potential uses in future empirical studies. It also aims to validate it for educational organizations, so the items were revised accordingly. There were three different study groups in the study. The first group included 33 English teachers and there were 150 teachers in the second and third study groups. First of all, a rigorous language adaptation process was carried out. Achieving language equivalency of the scale, exploratory and confirmatory factor analyses were conducted to test the construct validity. As for reliability, Cronbach's Alpha coefficient and items statistics were calculated. The findings showed that change fatigue scale had adequate psychometric properties when adapted into Turkish. A substantial theoretical contribution to the literature holds the significance of the current study. Additionally, the scale adapted into Turkish culture can be used in empirical studies in future and it can be a reference for further scale development efforts which can be regarded as the practical significance. The studies on change related constructs, organizational commitment, turn over intention, resilience and performance etc. can exploit the scale.
\end{abstract}

Keywords: Change fatigue, scale adaptation, reliability, validity.

* Orcid ID: https://orcid.org/0000-0002-5830-7561, Dr., Sakarya Mithatpaşa Anatolian High School, Turkey, ibomon@gmail.com 


\section{INTRODUCTION}

The era in which we live can be best described as a time of change. Change has become inevitable for organizations (Brown, Kulik, Cregan \& Metz, 2015; Gürses \& Helvacl, 2011) and organizational change has become a central issue within the organization theory (Quattrone \& Hopper, 2001). Nevertheless, today the speed of change is so high that the present is seen only when it is disappearing (Rezvani, Dehkordi \& Shamsollahi, 2012). Such an environment makes rapid change one of the most apparent features of today's organizations (Zarandi, Amirkabi \& Azimi, 2017). While bringing about some opportunities for organizations, change can have some detrimental effects such as change cynicism (Brown et al. 2015), change resistance (Johns \& Van de Ven, 2016) and uncertainty caused by change (Rafferty \& Griffin, 2006) as well. It is also stated in the literature that when change is too frequent, its risk breeding potential particularly increases (Huy, 2001 cited in Bernerth, Walker \& Harris, 2011). In this sense, Abrahamson (2000) introduces a new concept "change fatigue". On the other hand, Winter (2013) asserts that change fatigue can be traced back to Alvin Toffler's influential 1970 book titled Future Shock. In this book, Toffler (1970; cited in Winter, 2013) explains future shock as "shattering stress and disorientation that we induce in individuals by subjecting them to too much change in too short time." However, it can be said that change fatigue did not attract much attention in literature by millennium when change became a part of everyday life and much more rapid compared to the past.

Change fatigue is a new construct focusing on excessive organizational change (Perel, 2015). It emerges when change is perceived as never ending (Kirk \& Wall, 2010; Winter, 2013). Scott-Morgan, Hoving, Smit, and Slot (2001) define it as unfavourable effect of continouos change in systems, processes and organizational equipments on employees' ability to cope with change. According to another definition, it is the perception that too much change is taking place and the amount of change is more than needed (Bernerth et al. 2011; Falkenberg, Stensaker, Christine \& Haueng, 2005). Zink, Steimle, and Schroder (2008) state that change fatigue is an experience resulting from several unrelated change initiatives. Dool (2009) suggests a definition focusing on the result of change fatigue and articulates that it refers to a negative shift in the level of job satisfaction originating from continuous change. As can be understood from definitions given, unlike change cynicism and resistance, change fatigue can be said to have a more passive nature which causes its remaining unnoticed. However, Beaudan (2006) puts forwards some signs of change fatigue;

- the value / objective of change initiatives is questioned increasingly,

- change leaders feel stressful or quit,

- reluctance to share change related data or comment on it,

- other strategic initiatives are prioritized, and budget or other resources are diverted to them,

- the length of change initiative causes impatience,

- $\quad$ key leaders of change do not attend progress reviews. 
In literature, it is possible to come up with different coneptualizations of the experience referring to change fatigue. For example, the terms repetitive change syndrome (Abrahamson, 2003); reform fatigue (Smith, 2018); law of initiative fatigue (Reeves, 2009) and innovation fatigue (Lindsay, Perkins \& Karanjikar, 2009) are used interchangeably with change fatigue. However, in this study the approach and definition suggested by Bernerth et al. (2011) are preferred. According to their approach, change fatigue is a perception about the quantity of change initiatives not about their quality.

There has been a growing interest to the concept especially in business and health organizations (Brown, Wey \& Foland, 2018; Brown, 2016; Camilleri, Cope \& Murray, 2018; Dool, 2009; Elving, Hansma \& Boer, 2011; McMillan \& Perron, 2013; Perel, 2015). The studies showed that change fatigue can be associated with resilience, job satisfaction, job stress, locus of control, emotional burnout, organizational commitment, turnover intention, planned change and transformational change, evaluation of change, change management and negative reactions to change, unwillingness towards change, uncertainty and readiness for change, team work (Bernerth et al., 2011; Brown, 2016; Brown et al. 2018; Camilleri et al., 2018; Dool, 2009; Elving et al. 2011; Johnson et al, 2016; Lyle, Cunningham \& Gray, 2014; Perel, 2015). Additionally, demographics such as age, tenure and the number of changes experienced have a significant effect on change fatigue level (Camilleri et al. 2018; Elving et al. 2011). As can be seen from the variables mentioned above, change fatigue has important implications not only related to change but also to other types of organizational behavior.

Change fatigue can be a barrier both to the success of change initiatives (McMillan \& Perron, 2013) and organizational objctives. So, it is a problem that should be taken into consideration seriously. According to MacIntosh, Beech, McQueen and Reid (2007), it is of great importance to find novel ways to run daily operations in organizations while changing. Herein, Dool (2009) suggests that reducing the number of change initiatives is one of the most apparent remedies even if it seems unlikely. A second one is reframing the notion of change and creating a change management framework that encourages a more adaptive organization. To achieve this, organizations should reframe change as a usual phenomenon in organizational structure instead of treating change as an extraordinary organizational response. In this way, organizations can become more flexible and agile which in turn may reduce the negative aspects of change fatigue. On the other hand, in their book, The End of Change: How Your Company Can Sustain Growth and Innovation While Avoiding Change Fatigue, Scott-Morgan et al. (2001) proposes four different organizational structures to reduce the fatigue. However, the book does not provide practical solutions to the fatigue and it is based on the writers' subjective experiences. Based on this, it can be concluded that change fatigue is an organizational phenomenon that should be investigated more thoroughly to put forward further practical solutions. 
All in all, change is inevitable in today's dynamic environment and organizations have to operate in this environment. Unfortunately, this causes some challenges both for organizations and employees. Concerning educational organizations, just like others they also have to follow the opportunities and avoid threats in the contemporary turbulent environment (Martincic, 2010) which forces them to change (Burner, 2018; Jonasson, 2016). However, this pressure brings the frequent change to agenda for them as well (Education Week Research Center, 2017; Lyle et al. 2014) and when change is too frequent, it has the potential to cause change fatigue in educational organizations (Jeffrey, 2015; Leuschke, 2017; Lyle et al. 2014; Nunnelly, 2016).

\section{Change Fatigue in Educational Organizations}

In the implementation of educational policies, instead of rapid changes or short-term interventions aiming to solve current problems, it is crucial to put into practice policies which take into consideration the situational factors of the country, have a steady infrastructure and are proven to be effective (Akçamete, Büyükkarakaya, Bayraklı \& Sardohan Yıldırım, 2012). However, educational systems are forced to cope with more reform initiatives than they can handle (Karip, 2019). Moreover, because of changing paradigms in technology and knowledge it can be anticipated that educational systems, schools, teachers, students and teaching methods will go on changing at a high speed which means some risks for educational systems (Genç \& Eryaman, 2007). Aiming at school improvement (Burner, 2018), educational change may also result in fatigue when it is perceived as too frequent (Jeffrey, 2015; Kirk \& Wall, 2010; Leuschke, 2017; Lyle et al. 2014; Nunnelly, 2016). Reeves (2010) states that educational administrators with limited time, money and energy are required to implement increasing number of changes. With every change initiative, their resources are decreasing but the demands are increasing which is regarded as the source of change fatigue. Frequently changing curriculum (Lyle et al., 2014), changing educational technologies (Jeffrey, 2015) and professional development activities, educational reforms in general (Education Week Research Center, 2017) are among the factors reported to cause high level of change fatigue among teachers.

In literature change fatigue in educational organizations is associated with technology use and intention to use technology (Jeffrey, 2015); organizational culture, personorganization fit, turnover intention, emotional exhaustion, organizational commitment, support for change, satisfaction with manager (Leuschke, 2017) and authentic leadership (Nunnelly, 2016). Additionally, Kirk and Wall (2010) found that when teachers think that they have been through endless change, they consider quitting the job which shows that change fatigue is a substantial threat to educational systems. However, it can be said that the literature on the topic is still in its infancy particularly for educational organizations. Especially, in national literature it is a research area waiting to be explored thoroughly. Because findings show that teachers and other shareholders perceive Turkish educational system as changing very frequently (Can, 2014; Çam-Tosun, 2017; İbret, Avcıoğlu \& Recepoğlu, 2016; Kasapoğlu, 2016; Örücü, 
2014; Sezgin-Nartgün \& Gökçer, 2014 etc.) which creates a susceptible environment to change fatigue.

\section{Significance of the Study}

This study aims to bring a new and different perspective to educational change in national literature. Handling change fatigue, it gets the theoretical foundations of the topic. On the other hand, by validating change fatigue scale for educational organizations, the study will enable to analyze the perceptions of teachers who are primarily in charge of implementing change initiatives. Using the scale, the researchers can put forward some significant findings on related variables and based on demographic comparisons, the groups which are more sensitive to change fatigue can be detected. The results obtained through change fatigue scale may have substantial implications for both policymakers and school administrators in the process of policy making and managing change.

\section{Aim of the Study}

This study aims to adapt "Change Fatigue Scale" into Turkish cultural context revising the items for educational organizations.

\section{METHOD}

\section{Research Model}

This study aims to adapt "Change Fatigue Scale" into Turkish culture in scope of educational organizations. Cross-cultural adaptation of scales with proper processes enable researchers to carry out multicultural studies and contribute to international collaboration (Çapık, Gözüm \& Aksayan, 2018). Cultural adaptation also saves time, money and effort (Beauford, Nagashima \& Wu, 2009). Accordingly, it can be observed that scale adaptation studies are increasing nowadays (Açak \& Düz, 2018; Altundağ, Yandı \& Ünal, 2019; Dilekçi \& Sezgin Nartgün, 2020; Limon \& Durnalı, 2017; Yılmaz, 2019 e.g.). In this context, this is a cultural adaptation study which employs quantitative design.

\section{Study Group}

This study was carried out on three different study groups. The first group compromises of 33 English teachers. The data obtained from this group was used to check the language equivalency of Turkish version of the scale. On the other hand, there were 150 teachers in the second group. Data collected from this group was used in exploratory factor analysis (EFA) and reliability analysis. There were also 150 teachers in the last group on whose data CFA was carried out. According to Pallant (2007), the number of participants was sufficient both considering the sample size and item number-respondent ratio which is at least five respondents for each item in the scale for both analyses. Demographics of participants are presented in Table 1. 
Table 1

Demographics of participants

\begin{tabular}{llcccc}
\hline \multirow{2}{*}{ Variable } & Group & \multicolumn{2}{c}{ AFA } & \multicolumn{3}{c}{ CFA } \\
& & $\mathrm{n}$ & $\%$ & $\mathrm{n}$ & $\%$ \\
\hline \multirow{2}{*}{ Gender } & Female & 72 & 48 & 86 & 57.3 \\
& Male & 78 & 52 & 64 & 42.7 \\
\hline \multirow{3}{*}{ School type } & Primary & 34 & 22.7 & 63 & 42 \\
& Elementary & 34 & 22.7 & 32 & 21.3 \\
& High School & 82 & 54.7 & 55 & 36.7 \\
\hline \multirow{3}{*}{ Age } & $20-30$ & 19 & 12.7 & 25 & 16.7 \\
& $31-40$ & 51 & 34 & 74 & 49.3 \\
& $41-50$ & 68 & 45.3 & 42 & 28 \\
Experience & $51 \geq$ & 12 & 8 & 9 & 6 \\
& $0-5$ & 12 & 8 & 12 & 8 \\
& $6-10$ & 22 & 14.7 & 36 & 24 \\
& $11-15$ & 23 & 15.3 & 43 & 28.7 \\
& $16-20$ & 46 & 30.7 & 26 & 17.3 \\
& $21 \geq$ & 47 & 31.3 & 33 & 22 \\
& Total & 150 & 100 & 150 & 100 \\
\hline
\end{tabular}

As Table 1 shows, teachers in EFA group are evenly distributed in terms of gender. On the other hand, over half of the teachers (54.7\%) in this group work in high schools. Nearly half of them (45.3\%) are at the range of 41-50 and lastly, most of the teachers $(62 \%)$ have an experience of over 16 years.

As for CFA group, most of the teachers in this group are females (57.3\%) and work in primary schools (42\%). Almost half of them (49.3\%) are aged between 31-40 and lastly most of them (68\%) have an experience of over 11 years.

\section{Data Collection Tool}

"Change Fatigue Scale" was developed by Bernerth et al. (2011) to explore the impact of multiple organizational changes on employees. To adapt the scale into Turkish cultural context and for educational organizations, a mail seeking the consent of the researchers was sent. After receiving their consent, the adaptation process began. Since the study aimed to adapt the scale for educational organizations, the expressions of "employee" and "company" were replaced with "teachers" and "educational system". The original study was carried out in the U.S.A with change consultants of a manufacturing organization and yielded satisfactory results on validity and reliability. Exploratory factor analysis was conducted to test the validiy of the scale and the factor loadings were 
over .40. Cronabch's Alpha coefficient was found to be .85. As a valid and reliable measure, it was used several times in various cultural and organizational contexts (Brown, 2016; Camilleri et al. 2018; Jeffrey, 2015; Leuschke, 2017; Perel, 2015). All the studies mentioned reported the scale to be a valid and reliable measurement tool.

It is a unidimensional scale which has six items. The scale items are responded on a 7point format ranging from "Strongly Disagree (1)" to Strongly Agree (7)". However, a sevent-point format would cause difficulty in comprehension and ambiguity in meaning since the options would be very close to each other which would make it very difficult for respondents choose among the options (Şeker \& Gençdoğan, 2006). Additionally, five-point format is the most common one in educational studies Turan, Şimşek \& Aslan (2015) and examples of changing seven-point format into five-point one can be seen in literature (Dalatı, Raudeliūnienė \& Davıdavıčıenè, 2017; Doğan \& Akıncı Çötok, 2011; Limon, 2016).

As stated above, the validity and reliability of the scale was conducted on employees of a manufacturing company so while the items were translated into Turkish, they were revised for educational organizations. Additionally, they were rearranged according to five-point format ranging from "Strongly Disagree (1)" to "Strongly Agree (5). The mean score of the total scale can be calculated and evalution of arithmetic means are presented in Table 2 .

Table 2

Evaluation of arithmetic means

\begin{tabular}{ll}
\hline Mean & Evaluation \\
\hline $1.00-1.80$ & Strongly Disagree \\
$1.81-2.60$ & Disagree \\
$2.61-3.40$ & Undecided \\
$3.41-4.20$ & Agree \\
$4.21-5.00$ & Strongly Agree \\
\hline
\end{tabular}

\section{Data Analysis}

To analyze the data SPSS 25 and AMOS 23 statistical packages were used. The construct validity of the scale was analyzed through exploratory and confirmatory factor analyses. The reliability was assessed by Cronbach's Alpha internal consistency coefficient. Additionally, corrected item total statistics, mean difference between upper $27 \%$ and lower $27 \%$ groups' mean scores were calculated. Before the analysis of the data, missing values were checked, and it was observed that there was no missing value in data sets. Secondly, univariate outliers were detected, and it was observed thatthere were eight of them in exploratory factor analysis and seven in confirmatory factor analysis data set. 
Seeing that discarding outliers did not create a substantial difference on the findings and not to create a sample size problem, they were retained. Before carrying out correlation analysis for linguistic equivalency, normality assumption was checked for both data set obtained from English and Turkish versions of the scale. Skewness values for English and Turkish values were -.622 (S.E.=.409) and .980 (S.E.=.409), respectively; on the other hand, kurtosis values were .266 (S.E.=.798) and .603 (S.E.=.798). These findings indicated that both data sets satisfied normality assumption (Field, 2009), so Pearson correlation coefficient was calculated.

\section{Language Adaptation Process}

In the literature, various steps are suggested for scale adaptation (Beauford, Nagashima, \& Wu, 2009; Dhamani \& Richter, 2011; Gjersing, Caplehorn \& Clausen, 2010). However, this study employed the steps suggested by Gjersing et al. (2010). According to the researchers, the first step in a scale adaptation process is to investigate whether the items or concepts in the original scale has equivalency in target culture or not. In this step, three field experts analyzed the scale items and they stated that the scale can be adapted into Turkish culture. Secondly, the items are translated into target language (forward translation) which is Turkish in this study. In this step, the items were translated into Turkish by five field experts (in educational administration) who are also highly proficient in English. Next, the translations are synthesized which were done by two field experts. The synthesized version of the scale is translated into English again which is called back translation. In this study, back translations were done seperately by two academicians one of whom working in the U.S.A. The back translated versions are synthesized which was done by an academician again who got her Phd degree in the U.S.A. Experts check this version of the scale. An academician checked the synthesized version of the scale and no revision was suggested. Afterwards, a pilot implementation is carried out on the target group. Based on the feedback from the pilot implementation, the items are revised. The researcher checks the applicability of the scale and after this step scale is ready to be implemented for data collection. Before the main implementation, a pilot implementation was carried out in Sakarya. In addition to these steps, English teachers responded English and Turkish versions of the scale to check the language equivalency of scale statistically by calculating correlation coefficients between two measurements.

\section{FINDINGS}

\section{Findings on Language Equivalency}

To test the language validity of Turkish form of change fatigue scale statistically, Pearson correlation coefficient was calculated between English and Turkish measurements. In Table 3, findings of this analysis are presented. 
Table 3

Language Equivalency of Change Fatigue Scale

\begin{tabular}{lcccc}
\hline Version & $\mathrm{N}$ & $\overline{\mathrm{x}}$ & $\mathrm{sd}$ & $\mathrm{r}$ \\
\hline English & 33 & 4.51 & .52 & $.70^{* *}$ \\
Turkish & 33 & 4.25 & .52 & \\
${ }^{* *} p<.01$ & & & &
\end{tabular}

A correlation of $\mathrm{r}=.70$ indicates a positive strong correlation between English and Turkish versions of the scale (Russo, 2004). This finding can be interpreted as Turkish version of the scale having an equivalency to English one.

\section{Findings on EFA}

To determine the construct validity of the scale an EFA was carried out firstly since the original scale was developed for a manufacturing company and adapted to educational organizations in Turkish. The analysis was carried out based on the steps and criteria suggested by Huck (2012). In the first step, the suitability of data for a factor analysis was checked and a KMO > .60 and significant Bartlett's test of sphericity were sought. In the second and third steps, extraction and factor rotation methods were chosen which are factor analysis (maximum likelihood method) and varimax rotation respectively in this study. To determine the number of useful factors, eigenvalues greater than 1.00 was considered and the scree plot was checked. In the next step, to decide the variable make-up of the factors factor loadings greater than .40 were considered. The last step in the analysis is naming the factors or factor. Findings of aforementioned analyses are presented in the following section.

Table 4

KMO and Bartlett test of sphericity

\begin{tabular}{llc}
\hline Statistics & & Value \\
Kaiser-Meyer Olkin Sample Adequacy & & .81 \\
\hline \multirow{3}{*}{ Bartlett test of sphericity } & Chi square & 417.20 \\
& Degree of freedom (df) & 15 \\
& Significance (p) & .00 \\
\hline
\end{tabular}


Table 4 presents the findings on KMO and Bartlett test of sphericity. A KMO of .81 and significant Bartlett test of sphericity $(\mathrm{p}<.01)$ can be interpreted as data set being suitable for factor analysis.

After checking the assumptions for suitability of data set for factor analysis, the researcher went on EFA by extracting and rotating factors. At this point, eigenvalues and scree plot were examined. Findings of these two analyses are presented below.

Table 5

Eigenvalues and Explained Variance

\begin{tabular}{|c|c|c|c|c|c|c|}
\hline \multirow[b]{2}{*}{ Factor } & \multicolumn{3}{|c|}{ Initial Eigenvalues } & \multicolumn{3}{|c|}{ Extraction sums of squared loadings } \\
\hline & Total & $\begin{array}{c}\% \text { of } \\
\text { Variance }\end{array}$ & $\begin{array}{c}\text { Cumulative } \\
\%\end{array}$ & Total & $\begin{array}{c}\% \text { of } \\
\text { Variance }\end{array}$ & $\begin{array}{c}\text { Cumulative } \\
\%\end{array}$ \\
\hline 1 & 3.58 & 59.61 & 59.61 & 3.08 & 51.37 & 51.37 \\
\hline 2 & .77 & 12.77 & 72.38 & & & \\
\hline 3 & .66 & 10.92 & 83.30 & & & \\
\hline 4 & .48 & 7.94 & 91.24 & & & \\
\hline 5 & .31 & 5.08 & 96.32 & & & \\
\hline 6 & .22 & .68 & 100.00 & & & \\
\hline
\end{tabular}

Extraction Method: Maximum Likelihood

Table 5 presents eigenvalues and explained variance. Findings indicate that there is only a single factor with an eigenvalue above 1.00. On the other hand, variance explained by this factor is nearly \%51.37 which can be considered as sufficient (Büyüköztürk, 2011). Additionally, a jagged line in scree plot is present only for a single factor which supports the unidimensional structure of the scale. Since the scale presented a unidimensional structure, no rotation was run. 


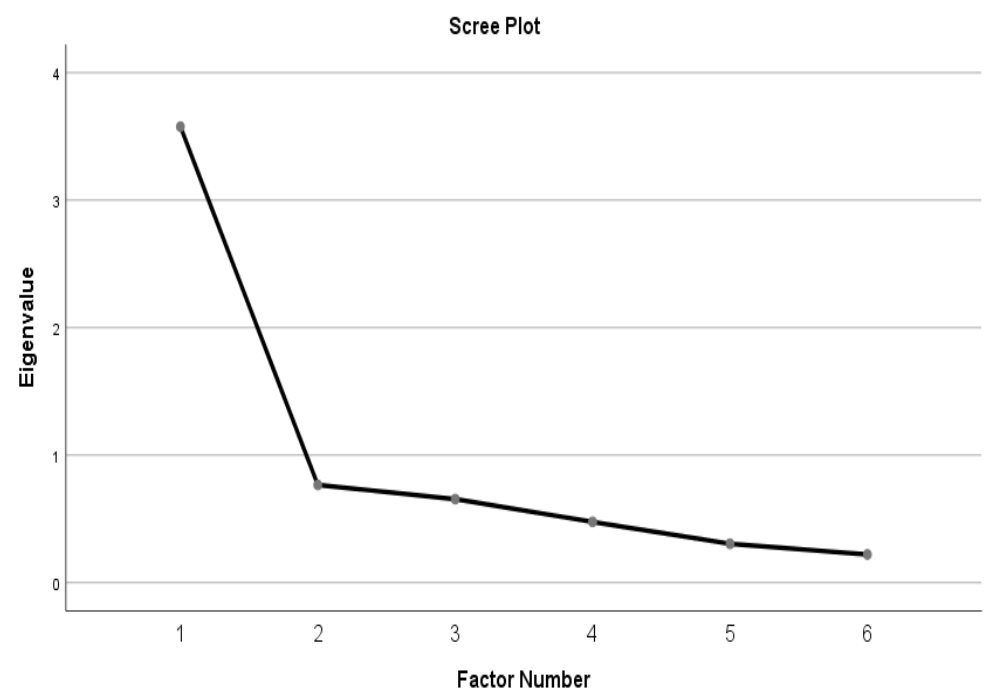

Figure 1. Scree plot

Table 6

Communalities and factor loadings

\begin{tabular}{lccccc}
\hline Item & $\mathrm{N}$ & $\overline{\mathrm{x}}$ & $\mathrm{sd}$ & Communalities & Factor Loadings \\
\hline 1 & 150 & 4.12 & 1.08 & .43 & .66 \\
2 & 150 & 3.92 & 1.09 & .50 & .71 \\
3 & 150 & 3.99 & 1.02 & .43 & .66 \\
4 & 150 & 3.92 & 1.00 & .72 & .85 \\
5 & 150 & 3.84 & 1.08 & .64 & .80 \\
6 & 150 & 4.36 & 1.06 & .37 & .61 \\
\hline
\end{tabular}

Table 6 presents communalities and factor loadings of items. While communalities range between .37 (Item 6) and .72 (Item 4), factor loadings range between .61 (Item 6) and .85 (Item 4). Considering the cut off values in literature (Büyüköztürk, 2011; Tabachnick \& Fidell, 2013; Huck, 2012), it can be said that these findings are satisfactory.

\section{Findings on Reliability}

Reliability was asssesed through Cronbach's Alpha coefficient and item statistics (comparing lower / upper \%27 groups' mean scores and corrected item total correlations). According to cut off values in the literature, Cronabch's Alpha should be greater than .70; differences between lower and upper \% 27 groups' mean scores should 
be statistically significant and corrected item total correlations should be greater than .30 (Büyüköztürk, 2011; Singh, 2007). The findings regarding these statistics are presented in Table 7.

Table 7

Reliability Statistics

\begin{tabular}{|c|c|c|c|c|c|c|c|c|}
\hline $\begin{array}{l}\text { Item } \\
\text { No }\end{array}$ & Group & $\mathrm{n}$ & $\bar{x}$ & $\mathrm{sd}$ & $\mathrm{t}$ & $\mathrm{p}$ & ITC & $\begin{array}{c}\text { Cronbach's } \\
\text { Alpha } \\
\text { if item deleted }\end{array}$ \\
\hline 1 & $\begin{array}{l}\text { Lower 27\% } \\
\text { Upper } 27 \%\end{array}$ & $\begin{array}{l}41 \\
41\end{array}$ & $\begin{array}{l}3.04 \\
4.95\end{array}$ & $\begin{array}{l}1.24 \\
.22\end{array}$ & -9.65 & .00 & .67 & .84 \\
\hline 2 & $\begin{array}{l}\text { Lower } 27 \% \\
\text { Upper } 27 \%\end{array}$ & $\begin{array}{l}41 \\
41\end{array}$ & $\begin{array}{l}2.92 \\
4.87\end{array}$ & $\begin{array}{r}1.17 \\
.33\end{array}$ & -10.27 & .00 & .66 & .84 \\
\hline 3 & $\begin{array}{l}\text { Lower 27\% } \\
\text { Upper 27\% }\end{array}$ & $\begin{array}{l}41 \\
41\end{array}$ & $\begin{array}{l}3.09 \\
4.92\end{array}$ & $\begin{array}{l}1.13 \\
.26\end{array}$ & -10.05 & .00 & .63 & .84 \\
\hline 4 & $\begin{array}{l}\text { Lower 27\% } \\
\text { Upper } 27 \%\end{array}$ & $\begin{array}{l}41 \\
41\end{array}$ & $\begin{array}{l}2.92 \\
4.82\end{array}$ & $\begin{array}{l}.98 \\
.38\end{array}$ & -11.54 & .00 & .73 & .83 \\
\hline 5 & $\begin{array}{l}\text { Lower 27\% } \\
\text { Upper 27\% }\end{array}$ & $\begin{array}{l}41 \\
41\end{array}$ & $\begin{array}{l}2.75 \\
4.82\end{array}$ & $\begin{array}{c}1.04 \\
.38\end{array}$ & -11.95 & .00 & .67 & .84 \\
\hline 6 & $\begin{array}{l}\text { Lower } 27 \% \\
\text { Upper } 27 \%\end{array}$ & $\begin{array}{l}41 \\
41\end{array}$ & $\begin{array}{l}3.36 \\
4.97\end{array}$ & $\begin{array}{c}1.42 \\
.16\end{array}$ & -7.18 & .00 & .58 & .85 \\
\hline $\begin{array}{l}\text { Total } \\
\text { Scale }\end{array}$ & $\begin{array}{l}\text { Lower } 27 \% \\
\text { Upper } 27 \%\end{array}$ & $\begin{array}{l}41 \\
41\end{array}$ & $\begin{array}{l}3.02 \\
4.89\end{array}$ & $\begin{array}{l}.74 \\
.17\end{array}$ & -15.93 & .00 & - & $\begin{array}{l}\text { Cronbach's } \\
\text { Alpha=.86 }\end{array}$ \\
\hline
\end{tabular}

According to independent samples t-test in Table 7, differences between upper and lower $27 \%$ groups' mean scores for all scale items and total scale are significant at .01 level. On the other hand, corrected item total correlations range between .58 (Item 6) and .73 (Item 4) which are all above .30. Cronbach's alpha coefficient of total scale is .86 . Based on all these findings, it can be stated that internal consistency of the items is satisfactory, and they are distinguishing individuals well (Büyüköztürk, 2011; Field, 2009). 


\section{Findings on CFA}

Following the EFA and reliability analyses, CFA was carried out. Since CFA was conducted on the data obtained from a different study group, Cronbach's Alpha coefficient was calculated again and it was .78 which was satisfactory (Büyüköztürk, 2011; Singh, 2007). In scope of CFA, goodness of fit indices, t-values and factor loadings of the items were checked. Factor loadings should be greater than .30 and t-values greater than 2.56 should be significant at .01 level (Kline, 2009; Ullman, 2013). In Table 8 , factor loadings and t values of items are presented.

Table 8

CFA item statistics

\begin{tabular}{lccc}
\hline Factor & Items & $\lambda$ & t-values \\
\hline & 1 & .31 & $3.57^{* *}$ \\
Factor 1 & 2 & .55 & $6.68^{* *}$ \\
& 3 & .51 & $6.20^{* *}$ \\
& 4 & .89 & $12.44^{* *}$ \\
& 5 & .81 & $10.99^{* *}$ \\
& 6 & .44 & $5.24^{* *}$ \\
\hline
\end{tabular}

As can be seen in Table 8, factor loadings of the items range from .31 (Item 1) to 89 (Item 4) and the t-values of all items are significant at $\mathrm{p}<.01$ level. Based on these findings, it can be said that all items satisfied the cut off values in literature. In Table 9, goodness of fit indices of change fatigue scale are presented.

Table 9

Cut off values for fit indices and values of fit indices for change fatigue scale

\begin{tabular}{lccl}
\hline Indices & Cut off value & Change Fatigue Scale & Evaluation \\
\hline${ }^{1} \mathrm{p}$ & $>.01$ & .19 & Good fit \\
${ }^{2}$ Chi-Square/ df & $\leq 5.00$ & 1.39 & Good fit \\
${ }^{2}$ RMSEA & $\leq .10$ & .05 & Good fit \\
${ }^{3}$ SRMR & $\leq .10$ & .04 & Good fit \\
${ }^{4}$ RMR & $\leq .80$ & .04 & Good fit
\end{tabular}




$\begin{array}{lccc}{ }^{1} \mathrm{NFI} & \geq .90 & .96 & \text { Good fit } \\ { }^{1} \mathrm{NNFI} & \geq .95 & .98 & \text { Good fit } \\ { }^{1} \mathrm{CFI} & \geq .90 & 99 & \text { Good fit } \\ { }^{1} \mathrm{GFI} & \geq .90 & .98 & \text { Good fit } \\ { }^{1} \mathrm{AGFI} & \geq .85 & .94 & \text { Good fit } \\ { }^{1} \mathrm{IFI} & \geq .90 & .99 & \text { Good fit }\end{array}$

Note: ${ }^{1}$ Schermelleh-Engel et al. (2003); ${ }^{2}$ Browne \& Cudek (1993); ${ }^{3}$ Worthington \& Whittaker (2006); ${ }^{4} \mathrm{Hu} \&$ Bentler (1999)

As Table 9 shows, all model fit values of change fatigue scale indicate "good fit" considering cut off values in literature. Based on these findings it can be said that unidimensional construct of change fatigue scale revealed by EFA is supported by CFA. The final model of change fatigue scale is presented in path diagram.

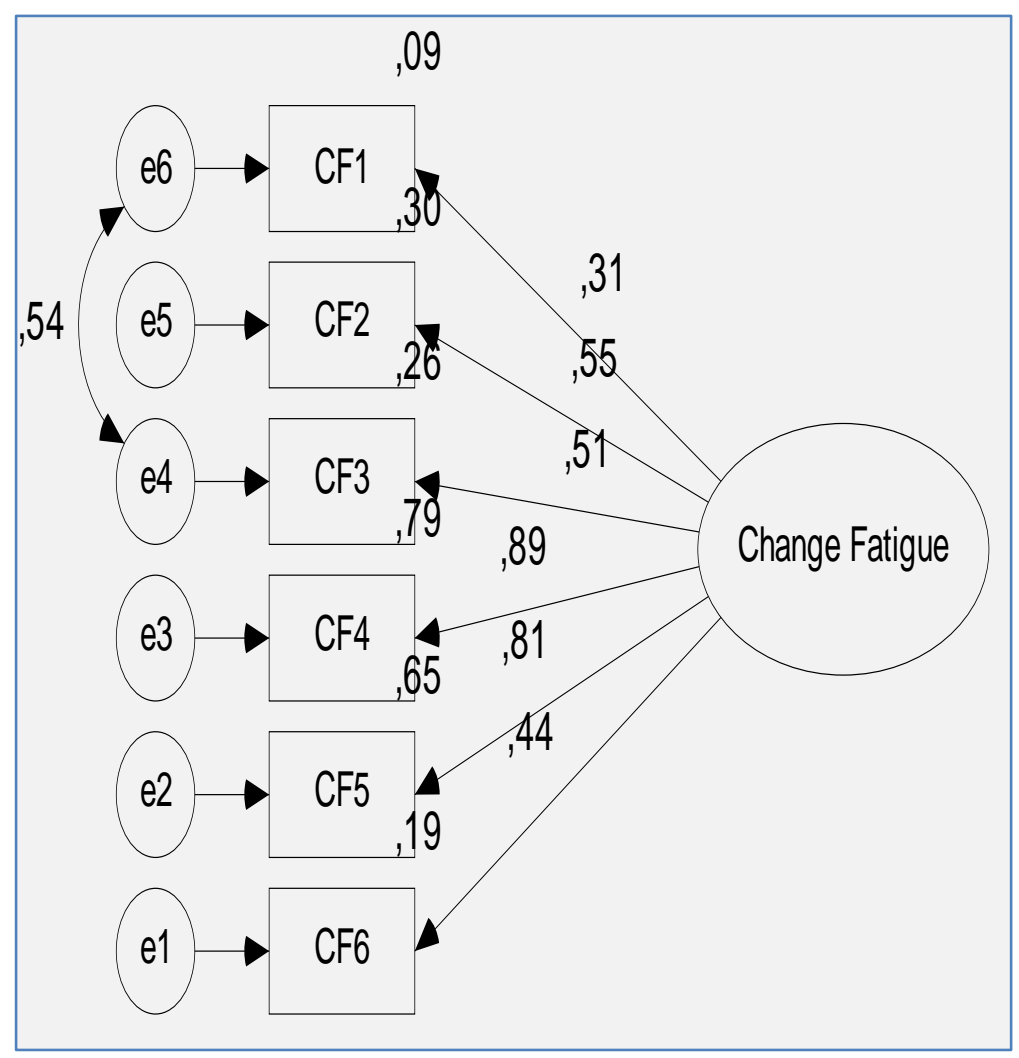

Figure 2. Change fatigue scale path diagram 


\section{CONCLUSIONS AND SUGGESTIONS}

The purpose of this study was to adapt "Change Fatigue Scale" into Turkish culture. The scale was originally developed for a manufacturing organization. However, the adaptation into Turkish was carried out for potential use in future empirical studies in educational organizations. In line with this aim, the items were revised for educational settings. First of all, a rigorous language adaptation process was conducted with the help of field experts who are proficient in original language which was English. For language adaptation, back translation method was employed (Ivir, 1981). After ensuring its linguistic equivalency, the correlation coefficient between the scores of English and Turkish versions was calculated. A high correlation coefficient supported language equivalency.

Since the target group of the original scale was different, an EFA was conducted in the initial step of the construct validity. The EFA yielded a unidimensional structure which was similar to original version of the scale (Bernerth et al. 2011). The single factor explained nearly half of the variance which can be deemed satisfactory (Büyüköztürk, 2011). On the other hand, all the factor loadings were above the cut off value in the literature (Büyüköztürk, 2011; Tabachnick \& Fidell, 2013; Huck, 2012).

Following EFA, reliability analysis of the scale was carried out. As an indication of internal consistency, Cronbach's Alpha coefficient was calculated which was .86. Based on this finding, it can be said that the scale has high internal consistency (Singh, 2007). Additionally, corrected item total correlations were all above .30 which supports the internal consistency. Statistically significant differences between lower and upper $27 \%$ groups' mean scores also showed that items can distinguish individuals well (Büyüköztürk, 2011). Thus, it can be said that the scale satisfied the cut off values for reliability and item statistics.

In scale development or adaptation studies the construct that emerges from EFA can be cross-validated by CFA (Huck, 2012). In this sense, factor loadings and t-values of the items were calculated, and goodness of fit indices were checked. Factor loadings were above the threshold value (Kline, 2009) and all the t-values were statistically significant (Ullman, 2013). Additionally, the fit indices indicated "good fit". Based on these findings, it can be said that CFA confirmed the unidimensional structure of the scale.

It can be concluded that "Change Fatigue Scale" has adequate psychometric properties when adapted into Turkish. Thus, it can be used to measure teachers' change fatigue level employed in all grade levels. Further studies can test the convergent validity of the scale using change related constructs such as change cynicism or resistance. Additionally, the scale can be exploited to make comparisons based on gender or experience after confirming its measurement invariance. Studies on the relationship between change fatigue and organizational behaviors such as turnover intention, organizational commitment, adaptive performance, change cynicism, resilience, organizational culture and job satisfaction can be carried out. International 
comparisons on change fatigue levels of teachers can be carried out using the adapted and original scale.

\section{References}

Abrahamson, E. (2000). Change without pain. Harvard Business Review, July-August.

Abrahamson, E. (2003). Change without pain: how managers can overcome initiative overload, organizational chaos, and employee burnout. Boston: Harvard Business Review Press.

Akçamete, G., Büyükkarakaya, H.S., Bayrakli, H. \& Sardohan Yıldırım, E. (2012). Eğitim politikalarının yansımaları: genel ve özel eğitim. Eğitim Bilimleri ve Uygulama, 11(22), 191-208.

Altundağ, Y., Yandı, A., \& Ünal, A. (2019). Uygulama temelli akıllı telefon bağımlılığı ölçeğinin Türk kültürüne uyarlama çalışması. Sakarya University Journal of Education, 9(2), 261281. DOI: $10.19126 /$ suje.516365.

Beaudan, E. (2006). Making change last: how to get beyond change fatigue. Ivey Business Journal, January / February. Retrieved from https://iveybusinessjournal.com/publication/making-change-last-how-to-get-beyondchange-fatigue/ on 12.11.2019.

Beauford, J. E., Nagashima, Y., \& Wu, M.H. (2009). Using translated instruments in research. Journal of College Teaching \& Learning, 6(5), 77-82.

Bernerth, J. B., Walker, H. J., \& Harris, S. G. (2011). Change fatigue development and initial validation of a new measure. Work \& Stress: An International Journal of Work, Health \& Organisations, 25(4), 321-337. DOI: 10.1080/02678373.2011.634280.

Brown, R., Wey, H., \& Foland, K. (2018). The relationship among change fatigue, resilience, and job satisfaction of hospital staff nurses. Journal of Nursing Scholarship, 50(3), 306-313.

Brown, R. (2016). Determining the relationship among change fatigue, resilience and job satisfaction of hospital staff nurses. (Unpublished doctoral dissertation). South Dakota State University, Dakota.

Brown, M., Kulik, C.T., Cregan, C. \& Metz, I. (2015). Understanding the change-cynicism cycle: The role of hr. Human Resource Management. DOI:10.1002/hrm.21708.

Browne, M. W., \& Cudeck, R. (1992). Alternative ways of assessing model fit. Sociological methods \& research, 21(2), 230-258.

Burner, T. (2018). Why is educational change so difficult and how can we make it more effective? Forskning \& Forandring, 1(1), 122-134. D0I:10.23865/fof.v1.1081.

Büyüköztürk, Ş. (2011). Sosyal bilimler için veri analizi el kitabı. Ankara: PegemA Akademi.

Camilleri, J., Cope, V., \& Murray, M. (2018). Change fatigue: the frontline nursing experience of large-scale organisational change and the influence of teamwork. Journal of Nursing Management, 27(3) 1-13.

Can, E. (2014). Türk eğitim sisteminde nitelik: Engeller ve öneriler. I.Avrasya Eğitim Araştırmaları Kongresi. İstanbul: İstanbul Üniversitesi.

Çam-Tosun, F. (2017). Öğrenci gözüyle geçmişten günümüze Türk eğitim sistemi. Uluslararası Eğitim Yönetimi Forumu (EYFOR 8). Ankara. 
Çapık, C., Gözüm, S. \& Aksayan, S. (2018). Kültürlerarası ölçek uyarlama aşamaları, dil ve kültür uyarlaması: Güncellenmiş rehber. Florence Nightingale Hemşirelik Dergisi, 26(3), 199-210. DOI: $10.26650 /$ FNJN397481.

Dhamani, K., \& Richter, M. (2011). Translation of research instruments: Research processes, pitfalls and challenges. African Journal of Nursing and Midwifery, 13(1), 3-13.

Dilekçi, Ü. \& Sezgin Nartgün, Ş. (2020). Öğretmenlerin algıladıkları uyumsal performans ölçeği'nin Türk kültürüne uyarlanması: Geçerlik-güvenirlik ve betimsel analiz. Hacettepe Üniversitesi Eğitim Fakültesi Dergisi, 35(2),448-465. DOI:10.16986/HUJE.2019052615

Doğan, T. \& Akıncı Çötok, N. (2011). Oxford mutluluk ölçeği kısa formunun Türkçe uyarlaması: Geçerlik ve güvenirlik çalışması. Türk Psikolojik Danışma ve Rehberlik Dergisi, 4(36), 165172.

Dool, R. (2009). Change fatigue: the impact of enervative change on job satisfaction. Revue Sciences de Gestion, 70, 21-40.

Düz, S. \& Açak, M. (2018). Sporun yaşam becerilerine etkisi ölçeğinin Türk kültürüne uyarlanması. İnönü Üniversitesi Eğitim Bilimleri Enstitüsü Dergisi, 5(9), 74-86. DOI: 10.29129/inujgse.360711.

Education Week Research Center. (2017). Teachers and Education Reform Results From a Natural Survey. Bethesda: Editorial Projects in Education.

Elving, W. J., Hansma, L. D., \& Boer, M. G. (2011). BOHICA: bend over here it comes again. TEORIJA IN PRAKSA, 48(6), 1628-1647.

Falkenberg, J., Stensaker, I. G., Meyer, C. B., \& Haueng, C. (2005). When change become excessive. Research in Organizational Change and Development, 15, 31-62.

Field, A. (2009). Discovering statistics using SPSS. Sage Publications: Los Angeles.

Genç, S.Z. \& Eryaman, M.Y. (2007). Değişen değerler ve yeni eğitim paradigması. Kocatepe Üniversitesi Sosyal Bilimler Dergisi, 9(1), 89-102.

Gjersing, L., Caplehorn, J. R. M., \& Clausen, T. (2010). Cross-cultural adaptation of research instruments: Language, setting, time and statistical considerations. BMC Medical Research Methodology, 10, 13. DOI:10.1186/1471-2288-10-13.

Gürses, G. \& Helvacl, M.A. (2011). Öğretmenlerin okullarda değişime direnme nedenleri. Uluslararası İnsanbilimleri Dergisi, 8(1), 1540-1563.

Hu, L., \& Bentler, P. M. (1999). Cutoff criteria for fit indexes in covariance structure analysis: Conventional criteria versus new alternatives. Structural Equation Modeling, 6(1), 1-55.

Huck, S. W. (2012). Reading statistics and research. Boston: Pearson Education.

Ivir, V. (1981). Formal correspondence vs. translation equivalence revisited. Poetics Today, 2(4), 51-59.

İbret, B. Ü., Avcı, E. K., \& Recepoğlu, S. (2016). Sosyal bilgiler öğretmen adaylarının toplumsal sorunların tespitine yönelik görüssleri. Abant İzzet Baysal Üniversitesi Eğitim Fakültesi Dergisi, 16(USBES Özel Sayı II), 1295-1319.

Jeffrey, D. A. (2015). Testing the technology acceptance model 3 (tam 3) with the inclusion of change fatigue and overload, in the context of faculty from seventh-day adventist universities: A revised model. (Unpublished doctoral dissertation). Andrews University School of Education, Michigan. 
Johnson, K. J., Bareil, C., Giraud, L., \& Autissier, D. (2016). Excessive change and coping in the working population. Journal of Managerial Psychology, 31(3), 739-755.

Jonasson, J. T. (2016). Educational change, inertia and potential futures. European Journal of Futures Research, 4(1), 1-14.

Johnson, K. J. (2016). The dimensions and effects of excessive change. Journal of Organizational Change Management, 29(3), 445-459.

Jones, S.L. \& Van de Ven, A.H. (2016). The changing nature of change resistance: an examination of the moderating impact of time. The Journal of Applied Behavioral Science, 52(4), 482506. DOI:10.1177/0021886316671409.

Kasapoğlu, H. (2016). Öğretmen adaylarının Türk eğitim sistemine ilişkin algılarının metaforlar yoluyla analizi. Kuram ve Uygulamada Eğitim Yönetimi, 22(1), 59-80.

Kline, R. B. (2009). Principles and practice of structural equation modeling. New York: The Guilford Press.

Leuschke, E. E. (2017). School culture and change fatigue in Tennessee. (Unpublished master thesis). Middle Tennessee State University, Tennessee.

Limon, İ., \& Durnalı, M. (2017). Adaptation of collaborative climate scale into Turkish: the study of validity and reliability. Sakarya University Journal of Education, 7(2), 282-294. DOI: 10.19126/suje.335818

Limon, İ. (2016). Örgütsel hafıza ölçeği'nin Türkçe'ye uyarlanması: Geçerlik ve güvenirlik çalışması. Sakarya University Journal of Education, 6(3), 8-19. DOI:.

Lindsay, J. D., Perkins, C. A., \& Karanjikar, M. R. (2009). Conquering innovation fatigue: Overcoming barriers to personal and corporate success. New Jersey: John Wiley \& Sons.

Lyle, J., Cunningham, C., \& Gray, J. (2014). The new Australian curriculum, teachers and change fatigue. Australian Journal of Teacher Education, 39(11), 45-64.

Martincic, R. (2010). Change management in adult educational organizations: A Slovenian case study. Managing Global Transitions, 8(1), 79-96.

MacIntosh, R., Beech, N., McQueen, J., \& Reid, I. (2007). Overcoming change fatigue: Lessons from Glasgow's National Health Service. Journal of Business Strategy, 28(6), 18-24.

McMillan, K., \& Perron, A. (2013). Nurses amidst change: The concept of change fatigue offers an alternative perspective on organizational change. Policy, Politics, \& Nursing Practice, 14(1), 26-32.

Örücü, D. (2014). Öğretmen adaylarının okul, okul yönetimi ve Türk eğitim sistemine yönelik metaforik algıları. Kuram ve Uygulamada Eğitim Yönetimi, 20(3), 327-358.

Pallant, J. (2007). Spss survival manual a step by step guide to data analysis using spss for windows. Berkshire: McGraw Hill.

Perel, C. (2015). Examining the relationship between organizational culture and change fatigue. (Unpublished master dissertation). Middle Tennessee State University, Tennessee.

Quattrone, P. \& Hopper, T. (2001). What does organizational change mean? Speculations on a taken for granted category. Management Accounting Research, 12, 403-435. D0I:: 10.1006/mare.2001.0176.

Rafferty, A. E., \& Griffin, M. A. (2006). Perceptions of organizational change: a stress and coping perspective. Journal of Applied Psychology, 91(5), 1154-1162. 
Razvani, S., Dehkordi, G.J. \& Shamsollahi, A. (2012). Managing strategic change for organizations. International Journal of Academic Research in Economics and Management Sciences, 1(3), 112-122.

Reeves, D. B. (2009). Leading change in your school: how to conquer myths, build commitment, and get results. Alexandria: ASCD.

Scott-Morgan, P., Hoving, E., Smit, H., \& Slot, A. V. (2001). The end of change : How your company can sustain growth and innovation while avoiding change fatigue. New York : McGraw Hill Books.

Schermelleh-Engel, K., Moosbrugger, H., \& Müller, H. (2003). Evaluating the fit of structural equation models: tests of significance and descriptive goodness-of-fit measures. Methods of Psychological Research Online, 8(2), 23-74.

Sezgin-Nartgün, Ş., \& Gökçer, İ. (2014). Pedagojik formasyon eğitimi alan öğretmen adaylarının mesleklerine, geleceklerine, istihdamlarına ve eğitim politikalarına ilişkin metaforik algiları. e-International Journal of Educational Research, 5(4), 57-69.

Singh, K. (2007). Quantitative social research methods. New Delhi: Sage Publications.

Smith, K. (2018). Accountability in teacher education in Norway: A case of mistrust and trust. C. Wyatt-Smith, \& L. Adie içinde, TInnovation and Accountability in Teacher Education: Setting Directions for New Cultures in Teacher Education (pp. 19-36). Singapore: Springer.

Şeker, H. \& Gençdoğan, B. (2006). Psikolojide ve eğitimde ölçme aracı geliştirme. Ankara: Nobel.

Tabachnick, B. G., \& Fidell, L. S. (2013). Using multivariate statiscs. New Jersey: Pearson Education.

Turan, İ., Şimşek, Ü., \& Aslan, H. (2015). Eğitim araştırmalarında likert ölçeği ve likert-tipi soruların kullanımı ve analizi. Sakarya Üniversitesi Eğitim Fakültesi Dergisi, 30(1), 186-203.

Ullman, J. B. (2013). Structural equation modeling. B. G. Tabachnick, \& L. S. Fidell içinde, Using Multivariate Statistics (pp. 681-785). Boston: Pearson.

Worthington, R. L., \& Whittaker, T. A. (2006). Scale development research a content analysis and recommendations for best practices. The Counseling Psychologist, 34(6), 806-838.

Yeşil, R., \& Şahan, E. (2016). Öğretmen adaylarının Türk eğitim sisteminin en önemli sorun, neden ve çözüm yollarına ilişkin algıları. Ahi Evran Üniversitesi Kırşehir Eğitim Fakültesi Dergisi, 16(3), 123-143.

Yılmaz, H. (2019). Kindarlık ölçeğinin Türk kültürüne uyarlanması ve kindarlığın demografik faktörlerle ilişkisi. E-Uluslararası Eğitim Araștırmaları Dergisi, 10(1), 50-66. DOI: 10.19160/ijer.533654.

Winter, A. J. (2013). The human cost of change: Tales from the campus about personal change fatigue, resistance, and resilience. (Unpublished Doctoral Dissertation). Queensland University of Technology, Brisbane City, Austalia.

Zarandi, H.M., Amirkabiri, A. \& Azimi, H. (2017). The role of organizational change on improving organizations financial and economic performance (case study: bank Shahr). A Quarterly Journal of Urban Economics and Management, 5(2), 117-130.

Zink, K. J., Steimle, U., \& Schroder, D. (2008). Comprehensive change management concepts development of a participatory approach. Applied Ergonomics, 39, 527-538. 
In the writing process of the study titled "Turkish Adaptation of Change Fatigue Scale: A Study of Reliability and Validity", the rules of scientific, ethical and citation were followed; it was undertaken by the authors of this study that no falsification was made on the collected data. "Sakarya University Journal of Education Journal and Editor" had no responsibility for all ethical violations to be encountered, and all responsibility belongs to the authors and that the study was not submitted for evaluation to any other academic publishing environment. 